\title{
ANALYSIS OF ICE CLIMBER SPORT PERFORMANCE DURING COMPETITION
}

\author{
Katarina Manovski ${ }^{1}$, Milivoj Dopsaj ${ }^{2}$, Vladimir Koprivica ${ }^{2}$, Milinko Dabović $^{2}$, Nenad Dikić ${ }^{3}$, \\ Marija Anđelković ${ }^{3}$ \\ ${ }^{1}$ University of Belgrade, Faculty of Sport and Physical Education, student MAS, Belgrade, Serbia \\ ${ }^{2}$ University of Belgrade, Faculty of Sport and Physical Education, Belgrade, Serbia \\ ${ }^{3}$ International Climbing and Mountaineering Federation, UIAA, Bern, Switzerland
}

\begin{abstract}
Sport discipline ice climbing was built on the reputation of climbing frozen waterfalls and can be defined as a unique discipline under the International Climbing and Mountaineering Federation (UIAA) in artificial, prescribed conditions, and according to certain rules. Due to the lack of articles about the motor activities of top ice climbers, the aim of this study is to determine sport performance of ice climbers, both genders, in discipline "lead climbing". Both genders are analysed, because in this sport discipline there is positive discrimination, due to the weaker characteristics of the female climbers. The propositions define that women and men have different climbing routes. Therefore, the sample were UIAA World Cup finalists in Beijing (2017) in lead climbing discipline, 8 men and 8 women. The method of work is the analysis of sport performance using the notation analysis. It was found that the average time of the race for men was 224.52 \pm 98.81 seconds, of which the active climbing time was $103.88 \pm 48.97$ seconds, while the passive climbing time - pauses was $119.66 \pm 50.40$ seconds. The average time of the race of women was $219.09 \pm 62.11$ seconds, of which the active climbing time was $108.52 \pm 31.37$ seconds, while the passive climbing time-pause was $110.58 \pm 41.42$ seconds. Although men and women climbed in a different direction, this analysis did not find the difference in sport performance between the gender, as well as in terms of the climbing pace and the type of technique used. The results of this analysis can be of great importance to trainers for practical work, for the immediate preparation of competitors for participation in UIAA ice climbing competitions.
\end{abstract}

Key words: ICE CLIMBING/ SPORT PERFOMANCE ANALISYS/ PACE/ UIAA

\section{INTRODUCTION}

Ice climbing is an extreme sport that has been part of traditional mountaineering. It means climbing frozen waterfalls or ice-covered walls - traditional ice climbing (Mashkovskiy et al., 2016). Ice climbing competitions (sports ice climbing) have developed from the climbing of frozen waterfalls, one of the discipline of alpinism.

Sports ice climbing, consisting of two disciplines -"lead" and "speed" climbing, can be defined as an extreme competitive climbing activity that takes place under the International Climbing and Mountaineering Federation (UIAA) in artificial, prescribed conditions, and according to certain rules (PractICEclimbing, UIAA). The competition polygon is very similar to the rock that is used for sport climbing competitions. In the "lead climbing” discipline, climbers hold their tools in the hands, which look like a mountaineering ice axes, and they are hooked on specially constructed climbing grips. On the legs, the competitors have sharply-pointed shoes, which look likea mountaineering crampon, and stab the metal peaks in the construction of the wall. Using various techniques that dictate the position of the grips and the construction of the wall, by clamping the tools and drilling the crampons into the wall, they compete vertically upwards with the aim of reaching the highest possible point. Each competitor has only one attempt to reach the top in a timeframe that is fixed and is the same for all competitors. The result of each competitor is based on the achieved height, except in 
cases when the competitor successfully reaches the top of the route, then the time is taken as a result. In the event that more competitors successfully complete the climb before the end of the scheduled time, the faster competitor will be better placed. In order to ensure a fair fight for everyone, competitors stay in an isolation zone prior to their appearance in which they have no opportunity to follow the sport performance of their opponents.

It is obvious that even in this discipline, as in other sports, the level of athlete's performance is measured at the competition. Technically-tactical, but also physical elements displayed at different levels of the competition are considered as an integral preparation of athletes (Viner et al., 2012). Integral preparation is the result of the process of combining, harmonizing and realizing various types of preparation (physical, technical, tactical, psychological, theoretical, affective in training and competition). The optimal level of integral preparation of athletes, which shows itself at the most appropriate moment is the basis for the achieving top results (Koprivica, 2013). The basis for rational approach to the problems of planning, programming, realization and evaluation of the effects of the systematic training process is in the analysis of sport performance. (Važni, 1978; Boženko, 1997; Nešić, 2002; Majstorović, 2015). Scientific research in sports should disclose information that sets knowledge in sports. Knowledge is necessary for better understanding of sports performance. Understanding sports allows the purpose of sport to be discovered (Nešić, 2006). So far there has been no research on the sport performance of sports ice climbers. Therefore, as the goal of this study is the analysis of quantitative characteristics of the structure of sport performance in ice climbing, in both genders, in climbing discipline - lead. The thesis is that the sport performance of ice climbers will have acceptable and reliable characteristics of central and dispersive statistical parameters; and that a difference will be noted between the structure of the sport performance in ice climbers in the function of the gender. For methodological reasons, and for the purpose of describing the sport performance, it is necessary to define information on the technical-tactical activities of top ice climbers, in both categories (men and women) that are being gathered in the competition. In this sport, as well as at other top competitions (world championships, Olympic Games ...), the success of the competitors is expressed through the achievement of an individual who is able to perform technique of respective sport at extremely high levels in a dynamic and unpredictable environment (Seifert et al., 2014).

\section{METHOD}

\section{Sample of subjects}

The sample of subjects consisted of the UIAA World Cup competitors in Beijing (2017) in both categories (men and women) who took part in the final round of ice climbing competition. The total number of analyzed competitors was 16, of which 8 men and 8 women.

\section{Sample of variables}

Notation technique analysis of competitive activities was used to collect data. The data from the official video clip UIAA are registered with the spread sheet. The results of the measurement were transmitted and processed in Microsoft Office EXCEL, version 2007. For each competitor, a notation sheet was filled in with noted techniques, time frame of the duration of movement and type of movement (active or passive). The following variables were observed:

- Total Climbing Time (TCT) - time elapsed since the start to the end of the competitor's performance, during one race. TCT was determined for each competitor individually, the average TCT of all competitors was calculated. The result is expressed in seconds (s).

- Active climbing time (ACT) - time spent for performing active movements (movements involving segment / body position change) within a single race. The ACT was determined for each competitor individually, the average active climbing time of all competitors was calculated. The result is expressed in seconds (s).

- Pauses (TP) - total pause time on the wall (no segment / body position change) within a single race. The TP of each competitor was determined individually, the average of the passive climbing time of all competitors was calculated. The result is expressed in seconds (s).

- Individual active movement (IAM) - the duration of the realization of a climbing technique, the active movement. The IAM was determined for each competitor individually, the average duration of the individual active movement for all competitors was calculated. The result is ex- 
pressed in seconds (s). The IAM variable is also expressed by the number of repetitions ( $\mathrm{n}$ ) - the frequency of applying the active movement during a single race.

- Single pause (SP) - duration of each pause. SP was determined for each competitor individually, the average duration of each break for each competitor was calculated. The result is expressed in seconds (s). The variable SP is also expressed by the number of repetitions (n), the frequency of applying the break during a single race.

- Climbing technique - a variable that talks about the type of climbing technique that competitors perform during a single race. The types of techniques were recorded individually for each competitor, the average of climbing techniques for all competitors were calculated during a single race. The result is expressed by the number of repetitions (n).

For the easier documentation of the climbing characteristics, all movements were classified: individual elements of climbing techniques and complex elements of climbing technique.

Individual elements of the climbing technique are simple to perform, they involve the stretching of one hand with the participation of the activity of legs, and the following elements of the climbing technique belong to them:

- Stretching right / left hand up, right (right hand right up, left arm up right)

- Stretching right / left hand up, left (right hand up left, left hand up left)

- Stretching right / left hand up, right (right hand right, left hand up right)

- Stretching right / left hand down, right (right hand down right, left hand down right)

- Stretching right hand down, right (right hand down right)

- Stretching right hand horizontally, right (right hand horizontal right)

- Stretching left hand down, left (left hand down left)

- Stretching left hand horizontally, left (left hand horizontally left)

The complex elements of the climbing technique have more complex mechanic pattern and require the active involvement of the whole body. The following climbing techniques are analysed as complex:
- Hand change (left tool, right hand; right tool, left hand)

- Figure four - the opposite leg goes over the opposite hand, for example, the right leg crosses the left hand and the left leg above the right hand

- Figure nine- right hand above the right leg or left hand above the left leg

- Attaching tool picks to the same grip (connection)

- Clipping

In addition to the absolute values of the variables, in terms of methodology, the relative values expressed in percent (\%) are calculated. All variables with relative values are calculated according to the standard mathematical principle: relative variable $=($ selected variable / original variable) x 100; Eg: Active climbing time $(\%)=($ Active climbing time $(\mathrm{s}) /$ Total climbing time $(\mathrm{s})) \times 100$.

\section{Data analysis}

Data processing is performed in the Microsoft Office EXCEL statistical sub-program, version 2007. Descriptive and comparative statistics are used for data processing. Descriptive statistical parameters determined for all variables were:

- Arithmetic Mean (Mean)

- $\quad$ Standard deviation (SD)

- Coefficient of variation (cV\%)

- Minimum value of the variables (Min)

- Maximum value of the variables (Max)

For the determination of the differences in arithmetic meanings in the function of a gender for the same variables, Student's t-test for non-contiguous samples was used. For the purposes of determining the differences between multiple pairs of variables of applied climbing technique, the variance analysis was used - ANOVA. Statistical significance was defined at 95\% probability for $\mathrm{p}<0.05$.

\section{RESULTS}

\section{Time parameters of the race in the function of gender}

Table 1 shows the results of the Student t-test and coefficient of variation for all time climbing indicators during a single race in both categories, men and women. 
Table 1. Results of Student t-test for time climbing parameters and coefficient of variation for men and women

\begin{tabular}{|l|c|c|c|c|c|c|}
\hline \multicolumn{1}{|c|}{ Variable } & M - MEAN & W - MEAN & t relation & p value & cV\%-M & $c V \%-W$ \\
\hline TCT (s) & 224.52 & 219.09 & 0.13 & 0.45 & 44.01 & 28.22 \\
\hline ACT (s) & 103.88 & 108.52 & 0.23 & 0.41 & 47.14 & 28.91 \\
\hline TP-pauses (s) & 119.66 & 110.58 & 0.39 & 0.35 & 42.12 & 41.14 \\
\hline ACT-relative (\%) & 45.20 & 50.34 & 1.37 & 0.10 & 12.54 & 18.94 \\
\hline TP-relative (\%) & 54.52 & 49.66 & 1.31 & 0.11 & 9.87 & 20.14 \\
\hline IAM-duration (s) & 6.98 & 6.77 & 0.21 & 0.42 & 53.33 & 31.04 \\
\hline SP-duration(s) & 10.16 & 8.60 & 1.17 & 0.13 & 52.40 & 36.74 \\
\hline
\end{tabular}

Leged: TCT- total climbing time, ACT- active climbing time, TP-total pause, IAM- individual active movement, SP-single pause, $\mathrm{cV} \%$-coefficient of variation

Based on the results of the Student t-test, it can be concluded that there was no statistically significant difference between the observed individual pairs of variables of the time indicators of the race in the function of the gender.
Technique elements in the function of gender

Table 2 shows the results of ANOVA analysis in the function of the applied elements of the techniques for men and women.

Table 2. Results of ANOVA in function of applied elements of the techniques for men and women

\begin{tabular}{|c|c|c|c|c|c|c|c|}
\hline \multicolumn{7}{|c|}{ Individual elements of climbing technique } \\
\hline Source of variation & SS & $d f$ & MS & F & P-value & F critical \\
\hline Between groups & 66.62 & 15 & 4.441 & 0.927 & 0.536 & 1.719 \\
\hline Withingroup & 920.15 & 192 & 4.792 & & & \\
\hline Total & 986.77 & 207 & & & & F critical \\
\hline \multicolumn{7}{|c|}{ Complex elements of climbing technique } \\
\hline Source of variation \\
\hline Between groups & 48.59 & 15 & 3.239 & 0.598 & 0.866 & 1.826 \\
\hline Within group & 346.80 & 64 & 5.419 & & & \\
\hline Total & 395.39 & 79 & & & & & \\
\hline
\end{tabular}

Based on ANOVA results, it can be concluded that there was no statistically significant difference between the observed pairs of variables of the analysed groups of technical elements in the function of gender.
The structure of competitive activities in ice climbers, lead climbing discipline, categories men and women had the following attributes and values (Table 3). 
Table 3. Structure of sport perfomance in both categories

\begin{tabular}{|c|c|c|}
\hline Structure of sport perfomance & Men & Woman \\
\hline Total climbing time & $224.5 \pm 98.81 \mathrm{~s}$ & $219.09 \pm 62.11 \mathrm{~s}$ \\
\hline Active climbing time & $\begin{array}{c}103.88 \pm 48.97 \mathrm{~s} \\
(45.20 \pm 5.67 \% \text { relative to total climbing } \\
\text { time })\end{array}$ & $\begin{array}{c}108.52 \pm 31.37 \mathrm{~s} \\
(50.34 \pm 8.99 \% \text { relative to total climbing time })\end{array}$ \\
\hline Pauses & $\begin{array}{c}119.66 \pm 50.40 \mathrm{~s} \\
(54.52 \pm 5.38 \% \text { relative to total climbing } \\
\text { time })\end{array}$ & $\begin{array}{c}110.58 \pm 41.42 \mathrm{~s} \\
(49.66 \pm 8.99 \% \text { relative to total climbing } \\
\text { time })\end{array}$ \\
\hline $\begin{array}{l}\text { Individual active movement- } \\
\text { duration }\end{array}$ & $6.98 \pm 3.69 \mathrm{~s}$ & $6.77 \pm 2.10 \mathrm{~s}$ \\
\hline $\begin{array}{l}\text { Number of active movements in } \\
\text { one race }\end{array}$ & $\begin{array}{c}14.38 \text { repetiton } \\
\begin{array}{c}\text { (54.96\% relative to number of total } \\
\text { movements })\end{array} \\
\end{array}$ & $\begin{array}{c}16.75 \text { repetition } \\
\text { (55.75\%relative to number of total } \\
\text { movements) }\end{array}$ \\
\hline Single pause & $10.16 \pm 5.68 \mathrm{~s}$ & $8.60 \pm 3.16 \mathrm{~s}$ \\
\hline $\begin{array}{l}\text { Number of single pause in one } \\
\text { race }\end{array}$ & $\begin{array}{c}11.63 \text { repetitions; } \\
\begin{array}{c}\text { (45.04\% relative to number of total } \\
\text { movements })\end{array}\end{array}$ & $\begin{array}{c}13.5 \text { repetitions } \\
\begin{array}{c}\text { (44.25\%relative to number of total } \\
\text { movements })\end{array}\end{array}$ \\
\hline The most used technique & $\begin{array}{l}\text { Technique connection with } 7.38 \pm 2.77 \\
\text { repetitions. }\end{array}$ & $\begin{array}{l}\text { Technique clipping with } 4.63 \pm 2.45 \\
\text { repetitions. }\end{array}$ \\
\hline
\end{tabular}

By analysing the notation sheet, it was found that men did not use the following climbing techniques: the left hand upward on the right, and vice versa, figure nine, left hand down right and left hand down to the left. In the sample of women, it is not determined using the left hand climbing techniques to the right and vice versa, figure nine, left hand down right, right hand down right, right hand down to the right.

\section{DISCUSSION}

The aim of this study was to determine the quantitative characteristics of the basic parameters of competitive ice climbers in both categories (men and women), in discipline lead climbing. Based on the results of descriptive indicators of average time during a single race in men and women (Table 1), it can be claimed that the value of the coefficient of variation in total, active and passive climbing-pause times in men exceeds $30 \%$ in absolute times. In women, the value of the total and active climbing time is below $30 \%$, while the passive climbing time is above $30 \%$.

The results found in men can be caused by the discrepancy of the duration of the movement - the climbing pace of all competitors. It is assumed that competitors who are more experienced and successful, simpler and easier elements of the technique perform faster in order to save energy for heavier parts. On the contrary, competitors who are less experienced choose a slower climb pace, ie, perform the given elements of a technique with a lower level of efficiency, and possibly with a lower level of economy.

The results indicate the equality of the duration of active movements, as well as the total climbing time in women. Possible cause of large differences from average results in passive climbing time(total pause) can be the result of competitive preparation, but also competitive experience. Practice has shown that weaker placed competitors spend more time in pause, thinking about next move, while more successful competitors solve this with shorter or even without unnecessary retention.

Results obtained in Table 3. show the basic descriptive indicators of the average duration of individual climbing (motion-movement) techniques in men and women during a single race. It can be concluded that in men the total number of active movements during one race was 14.38 reps (54.96\% compared to the total race time), while the pauses on average had 11.63 reps $(45.04 \%)$ compared to the total number of moves. Such results show that there are more active movements, in one climbing race than passive movements. Women, on average, use 16.75 active movements (55.75\%), and pauses 13.5 times (44.25\%) during one race. Women, unlike men, spend more time 
in active movement, and spend less time in pause (passive movements).

When analysing the relative indicators of the results, it was found that the active climbing time in men was $45.20 \%$, while at women was $50.34 \%$ compared to the duration of the race. This result is part of the difference in the pace that originates in the order, efficiency, and economy of movement, but is probably the consequence of gender and on it's better training and competitive preparation that is fact of a higher speed of movement. The active climbing time for women is longer, most likely due to a greater number of attempts to set up the tool, or put the legs in the right position. If an athlete fails on the first try to find the best handgrip, then the movement can be repeated without a break to the desired outcome. Future research should take into account also the type of active movement, whether it is worthwhile or not. This means that the realized elements of the technique should be analysed through the aspect of the applied climbing tactics. In addition, the total climbing time is around 224 seconds, which implies complex metabolic process that occur due to the overall involvement of the muscular system not comparable with other sports. We must not ignore the constant influence of the gravity force that requires more energy in opposing its intensity.

When analysing the relative duration of the pause, it is observed that during a single race in men it was $54.52 \%$ relative to the total climbing time, while in women, the passive climbing time was $49.66 \%$. The origin of this difference in result may be that men need a longer rest period because of the higher muscle mass they have comparing to women. Also, women may spend less time resting because of the rationality and prevalence of fat metabolism in the process for obtaining energy comparing to men (metabolic criteria) or climbing without much unnecessary retention (technical criteria). A pause on the rock is not a complete break, but it is also the period of fatigue; even its specific static component. Fatigue in sports has a complex nature and is still insufficiently studied. At the root of this fatigue is the temporarily disturbed internal balance of the organism, defined as allostasis-homeostasis, which main consequence is decreased working capacity (Fratric, 2015). Reduced competitive ability, if long lasting, can lead to a complete loss of competitiveness which finally lead to the end of an athlete's performance. Therefore, it is necessary for the competitors to carefully balance between recovery and fatigue during their performance. Reducing the competitive potential of an athlete in a short time is primarily conditioned by metabolic changes as response of the organism to highly intensive activities (Veljović et al., 2012). Both genders come to the competition results firstly by the technique. In the second and third steps, they differ in way that women dominantly based their result on endurance and then on strength, while the strength takes second and endurance third place in men.

Highly intensive activities are not only caused by physical fatigue, but by intellectual, sensory and emotional ones. For gender analysis, an interesting and significant analysis of the neuroendocrine origin of fatigue, in particular the participation of anabolic hormones (sympathetic origin) in relation to catabolic hormones (parasympathetic origin), would be interesting. Common to all of these types of fatigue is the impact on decision-making ability, choosing the best routes of climbing and applying the most appropriate technique ... Certainly, even the feeling of pace with a high degree of fatigue is „,compromised”.

Table 3 shows basic descriptive indicators of the frequency of realization of elements of climbing techniques in men and women during the analysed competition-climbing race. The notation analysis of the competition activities indicated that certain techniques were not used at the Beijing competition (right hand left, left hand to the right, left hand down right, right hand down right, left hand to the left, figure nine). The thesisi $s$ that the crossing movements (right hand to the left, left hand to the right) do not appear in ice climbing competitions due to the technical complexity of performance and physical difficulty, or the configuration of the wall and route set-up did not require the use of these techniques. Further research on this sport discipline that would be extended to other UIAA ice climbing competitions could verify those theses.

Based on the results of the coefficient of variation for all elements of the technique of over $30 \%$ in men implies a multiple way of solving the problem in climbing of each competitor (individual approach to a competitive result). The competitors used different techniques for overcoming the same problems on the competition route. In women, the value of the coefficient of variation is less than $30 \%$, only in the technique right-hand side is $14.24 \%$. This result can mean that most competitors have solved the problem in the same way, ie the route was set so that it was the easiest 
and most effective way to overcome it with this technique. Based on the results of the Student t-test, the difference in time indicators of the race between men and women found that there are no statistically significant differences in any of the analysed variables. On the basis of the obtained results, it was concluded that the total climbing time, on average, was 224.52 seconds in men, while in women it was 219.09s. These results indicate a similar structure of the time parameters of the sport performance in men and women, although they compete on different competitive paths (routes) on the wall of the same configuration. Based on the results of the analysis of the variance - ANOVA of the observed pairs of variables of the analysed groups of technical elements in the function of gender, there is no statistically significant difference for any variable (Table 2). This result suggests that the structure of the techniques applied by men and women in the competition does not differ, although they go in different directions, on the same construction, ie, wall. Thus, the whole problem returns to the time parameters, namely the pace of movement which, as the results show, significantly influence the order of the competitors. Choosing the right and most efficient pace of movement depends on the rhythm, the cognitive side of the competitor, but also the characteristics of the general and specific training before the competition. What is important to point out is, from a theoretical point of view, which may be useful in the application of this young sport, the fact that the pace belongs to the time parameters of the movement. That means that they originate from the parts of the motor cortex where there are no parameters for spatial side of the locomotion. In other words, the spatial and time parameters of movement are remembered in different parts of the motor cortex, which means that, learning and adopting them are determined by age. Time coordinating parameters are conditioned by early learning and specialization, while spatial parameters are determined by the muscular force as well as the morphological characteristics of athletes (Jevtić, 2011). Therefore, for the development of ice climbing, one of the first tasks is the setting of quality theory, methodology and training technology. On this path, it would also be important to create a multi-year program and an athlete's development program in the function of specializing in the challenges of this extreme sports discipline.

\section{CONCLUSION}

The subject of this study was to determine the structure of the sport performance in the discipline of lead climbing in the function of gender and pace.

The structure of the analysed ice-climbing performance has acceptable and reliable characteristics of central and dispersive statistical parameters. Although the men and women in the competition are climbing in different directions and have a different, predetermined time for this, there is no difference between the profile of the sport performance in the function of the gender; neither in terms of time parameters (pace), nor in terms of the type of applied technique.

Further research should have the aim, based on the consideration of specific characteristics of athletes, to acquire Know-how knowledge and / or technical skills related to procedures, processes, programs, standards ... in the context of specialization, as well as in the area of knowledge and philosophy of ice climbing itself.

The results obtained by this study can serve to model the training of competitors who will take part in UIAA World Cups in ice climbing with the ultimate goal of improving efficiency and achieving success in the competition.

Knowledge and information on the average duration of the competition race, the pace of movement, the duration of the pause and active movement, the type and frequency of the techniques applied will enable coaches and athletes to understand this relatively new competitive discipline.

The results of this study can help to further improvement the sport performance in ice climbing discipline. Future research, in order to obtain a more complete picture of the structure of sport performance of ice climbers and to confirm or deny the thesis of this study, should include all competitions that are held within the UIAA World Cup in ice climbing. 


\section{REFERENCES}

1. Boženko, A. (1997). Osnove teorije i metodike treninga fudbalera [Basic theory and methodology of football players training. In Serbian]. Beograd. Samostalno izdanje autora.

2. Fratrić, F. (2015). Teorija i metodika sportskog treninga [Theory and Methods of Sports Training.In Serbian]. Novi Sad, Pokrajinski zavod za sport.

3. Jevtić, B. (2011). Dečiji uzrast i razvoj koordinacionih sposobnosti: primer iz sportskog plivanja. [Childhood and development of coordination capacities: an example of sports swimming. In Serbian]. In B. Jevtic, J. Radojević. I. Juhas \& R. Ropret (Eds). Dečiji sport od prakse do akademske oblasti (pp. 187-197). Beograd. Fakultet sporta i fizičkog vaspitanja.

4. Lead Finals Ice Climbing Worldcup 2017. Beijinghttps://www.youtube.com/watch?v=4vB$\mathrm{w} 8 \mathrm{NTuD} 5 \mathrm{c} \& \mathrm{t}=6224 \mathrm{~s}$ (available 14.07.2017.).

5. Majstorović N., Sikimić M., Osmankač N., Grbić V. (2015). Analiza takmičarske aktivnosti u završnici „WIENER STADTISCHE” lige Srbije za odbojkaše u sezoni 2012/2103 [Competitive activitiy analysis in play-off stage of „WIENER STADTISCHE“ Serbian volleyball league for men in 2012/2013 season.In Serbian]. Fizička kultura, 69 (1), 51-58.

6. Mashkovskiy E., Beverly J.M., Stöcker U., Bychkovskiy S. (2009). Ice Climbing Festival in Sochi 2014 Winter Olympics: Medical Management and Injury Analysis. Wildernesse Environmental Medicine, 27, 117-124.
7. Nešić, G. (2002). Osnovi antropomotorike [Fundamentals of anthropomotorics. In Serbian]. Beograd: Sportska akademija.

8. Nešić G. (2006). Struktura takmičarske aktivnosti u ženskoj odbojci. [ Structure of competitive activity in women's volleyball. In Serbian]. Doctoral dissertation. Beograd. Fakultet sporta i fizičkog vaspitanja.

9. PractICEClimbinginCompetition, Athletes Manual, UIAA, Bern.

10. Seifert L., Wattebled L., Herault R., Poizat G., Ade' D., et al. (2014). Neurobiological Degeneracy and Affordance Perception Support Functional Intra-Individual Variability of Inter-Limb Coordination during Ice Climbing. PLoS ONE 9(2): e89865.hidoi:10.1371/journal.pone.0089865.

11. Važni, Z. (1978). Sistem sportskog treninga. [Sports training system. In Serbian] Beograd: Novinsko izdavačko preduzeće Partizan.

12. Viner I.A., Terekhina R.N., Pirozhkova E.A. (2012). Analysis of competitive activity of gymnasts in group exercices on the eve of the XXX Olympic games. Uchenyezapiski universitetaimeni P.F. Lesgafta, 76(4), 26-31.

13. Veljović D., Međedović B., Ostojić SM. (2012). Oporavak vrhunskih sportista: pregled savremenih metoda [Recovery of top athletes: a review of contemporary methods. In Serbian]. TIMS, Acta 6(1), 10-18. 


\section{ANÁLISIS DE LAS ACTIVIDADES COMPETITIVAS DE LOS ESCALADORES EN HIELO}

\section{Resumen}

La disciplina competitiva de escalada en hielo, surgió respondiendo a la escalada en cataratas congeladas y se puede definir como una disciplina deportiva particular que se desarrolla bajo el auspicio y proposiciones de la Federación Internacional de Asociaciones de Alpinismo (UIAA). Se desarrolla en las condiciones artificiales prescritas y bajo determinadas reglas. Por falta de trabajos sobre la actividad motriz de escaladores en hielo de alto rendimiento, el objetivo del presente trabajo es establecer la estructura de la actividad competitiva de los escaladores en hielo en las dos competencias (hombres y mujeres), en la disciplina escalada de plomo. Se analizan las dos competencias porque en esta disciplina deportiva por la discriminación positiva y por los atributos más débiles del organismo femenino para la escalada, las proposiciones prescriben que mujeres y hombres tienen distintas direcciones de escalada. Por esto, la muestra de los examinados se hizo de los finalistas de la copa mundial de UIAA en Pekín (2017) en la disciplina escalada de plomo y fueron 8 hombres y 8 mujeres. El método de trabajo es análisis de la actividad competitiva aplicando la técnica de análisis de notación. Se estableció que el tiempo promedio de duración de la carrera competitiva en los hombres ascendió a 224,52 $\pm 98,81$ segundos, de lo que el tiempo activo de escalada ascendía a 103.88 \pm 48.9 segundos y el tiempo pasivo de escalada - pausa ascendió a $110.58 \pm 41.42$ segundos. Aunque los hombres y mujeres en la competencia escalan por distintas direcciones, este análisis no estableció la diferencia entre la estructura de la actividad competitiva en función del sexo, como tampoco en cuanto al ritmo de escalada y tipo de técnica aplicada. Los resultados de este análisis pueden tener importancia excepcional para los entrenadores en su trabajo práctico para la preparación directa de los competidores para la participación en las competencias de UIAA.

Palabras claves; ESCALADA EN HIELO / ANÁLISIS DE ACTIVIDAD COMPETITIVA / RITMO / UIAA

Reacived: 03. 05. 2018. Accepted: 05. 06. 2018. 


\title{
АНАЛИЗА ТАКМИЧАРСКЕ АКТИВНОСТИ ПЕЊАЧА НА ЛЕДУ
}

\author{
Катарина Мановски ${ }^{1}$, Миливој Допсај ${ }^{2}$, Владимир Копривица ${ }^{2}$, Милинко Дабовић $^{2}$, \\ Ненад Дикић ${ }^{3}$, Марија Анђелковић ${ }^{3}$ \\ ${ }^{1}$ Универзитет у Београду, Факултет спорта и физичког васпитања, студент МАС, Београд, Србија \\ ${ }^{2}$ Универзитет у Београду, Факултет спорта и физичког васпитања, Београд, Србија \\ ${ }^{3}$ Међународна планинарска и пењачка организација, UIAA, Берн, Швајцарска
}

\begin{abstract}
Сажетак
Такмичарска дисциплина пењање на леду, настала је по угледу на пењање залеђених водопада и може се дефинисати као посебна спортска дисциплина која се под окриљем и пропозицијама Међународне пењачке и планинарске федерације (UIAA) одвија у вештачким, прописаним условима, и по одређеним правилима. 3ठог непостојања радова о моторичкој активности врхунских пењача на леду, циљ ово рада је да утврди структуру такмичарске активности код пењача на леду оба пола (мушкарци и жене), у дисциплини тежинско пењање. Анализирају се оба пола, јер се у овој спортској дисциплини ради позитивне дискриминације, а услед слабијих атрибута женског организма за пењања, пропозицијама прописује да жене и мушкарци имају различите смерове пењања. Стога, узорак испитаника су чинили финалисти светског купа UIAA у Пекингу (2017) у дисциплини тежинско пењање, и то 8 мушкараца и 8 жена. Метод рада је анализа такмичарске активности применом технике нотационе анализе. Утврђено је да просечно време трајања такмичарске трке код мушкараца износило $224.52 \pm 98.81$ секунди, од чега је активно време пењања износило $103.88 \pm 48.97$ секунди, а пасивно време пењања - паузе $119.66 \pm 50.40$ секунди. Просечно време трајања трке код жена износило је $219.09 \pm 62.11$ секунди, од тога је активно време пењања износило $108.52 \pm 31.37$ секунди, а пасивно време пењања - паузе износило је $110.58 \pm 41.42$ секунди. Иако се мушкарци и жене на такмичењу пењу различитим смером, овом анализом није утврђена разлика између структуре такмичарске активности у функцији пола, као ни у погледу темпа пењања и врсте примењиване технике. Резултати ове анализе могу бити од изузетног значаја тренерима за рад у пракси и то за непосредну припрему такмичара за учешће на такмичењима UIAA.
\end{abstract}

КљУчне речи: ПЕЊАЮЕ НА ЛЕДУ/ АНАЛИЗА ТАКМИЧАРСКЕ АКТИВНОСТИ / ТЕМПО/ UIAА/

\section{УВОД}

Пењање на леду је екстреман спорт који је током историје био део традиционалног планинарења, и означава пењање залеђених водопада или стена прекривених ледом - традиционално пењање на леду (Mashkovskiy et al., 2016). Такмичења у пењању на леду (спортско пењање на леду) су настала по угледу на пењање по залеђеним водопадима, једне од дисциплине алпинизма.

Спортско пењање на леду, које се састоји из две дисциплине - тежинско и брзинско пењање, може се дефинисати као екстремна такмичарска пењачка активност која се одвија под окриљем међународне пењачке и планинарске федерациje (UIAA) у прописаним, вештачким условима
(PractICE climbing, UIAA). Такмичарски полигон је врло сличан стени која се користи за такмичења спортског пењања. У дисциплини „тежинско пењање“, пењачи у рукама држе алатке, које подсећају на планинарски цепин, и њима се каче на специјално конструисана хватишта. На ногама такмичари имају ципеле са шиљастим врхом, који подсећа на планинарску дерезу, и забијају металне врхове у конструкцију стене. Применом различитих техника које диктира распоред хватишта и конструкција стене, качењем алатки за хватиште и забијањем дереза у стену такмичарски се пењу вертикално на горе са циљем освајања врха - доласка до највише могуће тачке. Сваки такмичар има само један покушај да стигне до врха и то у временском оквиру који је унапред одређен и исти 
је за све такмичаре. Резултат сваког такмичара је заснован на постигнутој висини, осим у случају када такмичар успешно достигне врх смера, тада се као резултат узима постигнуто време. У случају да више такмичара успешно заврши пењање пре истека предвићеног времена, бржи такмичар биће боље пласиран. Да би се осигурала фер борба за све, такмичари пре свог наступа бораве у изолационој зони у којој немају могућности да прате такмичарску активност својих претходника.

Очито је да се и у овој дисциплини, као и у другим спортовима, провера нивоа достигнућа спортиста обавља на такмичењу. Техничко-тактички, али и кондициони елементи приказани на различитим нивоима такмичења, сматрају се средством интегралне припремљености спортиста (Viner et al. 2012.). Интегрална припремљеност је резултат процеса којим се у тренингу и такмичењу обједињују, усклађују и реализују различите врсте припрема (физичка, техничка, тактичка, психолошка, теоријска, афективна...). Оптималан ниво интегралне припремљености спортисте, који се манифестује у најпогоднијем тренутку, основа је остваривања врхунских резултата (Копривица, 2013). Основа за рационалан приступ проблематици планирања, програмирања, реализације и евалуације ефеката систематског тренажног процеса, налази се у анализи такмичарске активности (Важни, 1978; Боженко, 1997; Нешић 2002, Мајсторовић 2015).

Научна истраживања у спорту треба да откривају сазнања која допуњују системе знања у спорту. Знања су неопходна да би се спортске активности у спорту могле разумети. Разумевање спорта омогућује да се открије смисао спорта (Нешић, 2006). До сада није било истраживања о такмичарској активности спортских пењача на леду, стога се као циљ овог првенца издваја анализа квантитативних карактеристика структуре такмичарске активности код пењача на леду у обе конкуренције, у дисциплини тежинско пењање. Претпоставка је да ће структура такмичарске активности код пењача на леду имати прихватљиве и поуздане карактеристике централних и дисперзивних статистичких параметара, те да ће се утврдити разлика између структуре активности код пењача на леду у функцији пола. Из методолошких разлога, а за потребе описа структуре такмичарске активности неопходно је дефинисати информације о техничко-тактичким активностима врхунских пењача на леду оба пола (мушкарци и жене) које се реализују на такмичењу. И у овом спорту, као и на осталим врхунским такмичењима (светска првенства, олимпијске игре...) успех такмичара се изражава кроз постигнуће појединца који је у стању да на изузетно високом нивоу изводи технику датог спорта у динамичном и непредвидивом окружењу (Seifert et al., 2014).

\section{МЕТОД РАДА}

\section{Узорак испитаника}

Узорак испитаника чинили су финалисти Светског купу UIAA у Пекингу (2017) оба пола (мушкарци и жене), који су учествовали у финалној рунди такмичења у пењању на леду. Укупан број анализираних такмичара био је 16 , од чега 8 мушкараца и 8 жена.

\section{Узорак варијабли и инструменти}

За прикупљање података коришћена је техника нотационе анализе такмичарске активности. Подаци са званичног видео снимка UIAA-а бележени су на нотациони лист. Резултати мерења пренети су и обрађени у програму MicrosoftOfficeEXCEL, верзија 2007. За сваког такмичара попуњен је нотациони лист у коме су забележене примењиване технике са временским оквиром трајања кретања, врста покрета, карактер и трајање паузе (активна или пасивна). Праћене су следеће варијабле:

- укупно време пењања (УВП) - време протекло од старта до краја наступа такмичара, током једне трке. Утврђено је УВП за сваког такмичара појединачно, израчунат је просек УВП свих такмичара. Резултат је исказан у секундама (s);

- активно време пењања (АВП) - време утрошено за извођење активних покрета (покрети који укључују промену положаја сегмента/тела) у оквиру једне такмичарске трке. Утврђено је АВП за сваког такмичара појединачно, израчунат је просек активног времена пењања свих такмичара. Резултат је исказан у секундама (s);

- паузе (УП)- укупно време пауза на стени (нема промене положаја сегмента/тела) у оквиру једне такмичарске трке. Утврђено је УП сваког такмичара појединачно, израчунат је просек пасивног времена пењања свих такмичара. Резултат је исказан у секундама (s); 
- појединачан активни покрет (ПАП) - време трајања реализације једне технике пењања, активно извођење покрета. Утврђен је ПАП за сваког такмичара појединачно, израчунат је просек трајања појединачног активног покрета за све такмичаре. Резултат је исказан у секундама (s). Варијабла ПАП је изражена и кроз број понављања (n) - учесталост примене активног покрета током једне такмичарске трке;

- појединачна пауза (ПП) - време трајања сваке паузе. Утврђена је ПП за сваког такмичара појединачно, израчунат је просек трајања сваке паузе за све такмичаре. Резултат је исказан у секундама (s). Варијабла ПП је изражена и кроз број понављања (n), учесталост примене паузе током једне такмичарске трке.

- техника пењања - варијабла која говори о врсти технике пењања (покрета, кретања) које такмичари реализују током једне такмичарске трке. Бележене су врсте технике за сваког такмичара појединачно, израчунат је просек утврђених техника пењања за све такмичаре, током једне такмичарске трке. Резултат је исказан бројем понављања (n).

Ради лакшег препознавања и евидентирања атрибута пењања, сва кретања су класификована као: појединачни елементи технике пењања и комплексни елементи технике пењања.

Појединачни елементи технике пењања су једноставни за извођење, подразумевају опружање једне руке уз учешће активности ногу, и њима припадају следећи елементи технике пењања:

- опружање десне/леве руке горе, право (десна рука горе право, лева рука горе право);-

- опружање десне/леве руке горе, лево (десна рука горе лево, лева рука горе лево);

- опружање десне/леве руке горе, десно (десна рука горе десно, лева рука горе десно);

- опружање десне/леве руке доле, право (десна рука доле право, лева рука доле право);

- опружање десне руке доле, десно (десна рука доле десно);

- опружање десне руке хоризонтално, десно (десна рука хоризонтално десно);

- опружање леве руке доле, лево (лева рука доле лево);

- опружање леве руке хоризонтално, лево (лева рука хоризонтално лево).

Комплексни елементи технике пењања имају сложенији моторички образац извођења и захтевају активно учешће целог тела. Као комплексна, анализиране су следеће технике пењања: промена руку (лева алатка, десна рука; десна алатка, лева рука)

- фигура четворка - (супротна нога иде преко супротне руке, на пример десна нога прелази леву руку и леву ногу над десном руком);

- фигура деветка - десна рука изнад десне ноге или лева рука изнад леве ноге;

- стављање врхова алатки на исти хват (спајање);

- копчање.

У методолошком смислу, поред апсолутних вредности варијабли, израчунате су и релативне вредности које су изражене у процентима (\%). Све варијабле са релативним вредностима су израчунате у складу са стандардним математичким принципом и то: релативна варијабла = (изабрана варијабла / оригиналном варијаблом) х 100; нпр.: активно време пењања $(\%)=($ активно време пењања (s) / укупно време пењања (s)) х 100.

\section{Обрада података}

Обрада података је извршена у статистичком потпрограму програма MicrosoftOfficeEXCEL, верзија 2007. Од дескриптивних статистичких параметара за све праћене варијабле су израчунате:

- аритметичка средина варијабле (Mean);

- стандардна девијација (SD);

- коефицијент варијације (cV\%);

- минимална вредност варијабли (Min);

- максимална вредност варијабли (Мах).

За утврђивање разлика аритметичких средина у функцији пола код истих варијабли коришћен је Студентов t-тест за неупарне узорке. За потребе утврђивања разлика између вишеструких парова варијабли примењених елемената технике пењања коришћена је анализа варијансе - ANOVA. Статистичка значајност је дефинисана на нивоу $95 \%$ вероватноће за $\mathrm{p}<0.05$.

\section{РЕЗУЛТАТИ}

\section{Временских параметара трке у функцији пола}

У Табели 1 су приказани резултати Студентовог $\mathrm{t}$-теста за све временске показатеље пењања током једне такмичарске трке код мушкараца и жена. 
Мановски К. и сар., Анализа такмичарске активности пењача на леду, ФИЗИЧКА КУЛТУРА 2018; 72 (1): 80-88

Табела 1. Резултати Студентовог $\mathrm{t}$-теста за временске параметре пењања код мушкараца и жена

\begin{tabular}{|c|c|c|c|c|}
\hline Варијабла & M - MEAN & Ж - MЕАN & т релација & р вредност \\
\hline УВП (s) & 224.52 & 219.09 & 0.13 & 0.45 \\
\hline АВП (s) & 103.88 & 108.52 & 0.23 & 0.41 \\
\hline ПВП-паузе (s) & 119.66 & 110.58 & 0.39 & 0.35 \\
\hline АВП-релативно (\%) & 45.20 & 50.34 & 1.37 & 0.10 \\
\hline ПВП-релативно (\%) & 54.52 & 49.66 & 1.31 & 0.11 \\
\hline ПАП-време трајања (s) & 6.98 & & & 0.42 \\
\hline ППП-време трајања (s) & 10.16 & 8.77 & 0.21 & 0.13 \\
\hline
\end{tabular}

Легенда: УВП-укупно време пењања, АВП- активно време пењања, ПАП-појединачан активни покрет, ПП-појединачна пауза

На основу резултата Студентовог t- теста може се констатовати да није утврђена статистички значајна разлика између посматраних појединачних парова варијабли временских показатеља трка у функцији пола.

\section{Елемената технике у функцији пол}

У Табели 2 приказани су резултати ANOVA анализе у функцији примењених елемената технике код мушкараца и жена.

Tабела 2. Резултати ANOVA у функцији примењених елемената технике пењања (мушкарци и жене)

\begin{tabular}{|c|c|c|c|c|c|c|}
\hline \multicolumn{5}{|c|}{ Појединачни елементи технике пењања } & \multirow[b]{2}{*}{ Р-вредност } & \multirow[b]{2}{*}{ F критична } \\
\hline Извор варијације & SS & $d f$ & MS & $F$ & & \\
\hline Између група & 66.62 & 15 & 4.441 & 0.927 & 0.536 & 1.719 \\
\hline Унутар групе & 920.15 & 192 & 4.792 & & & \\
\hline Укупно & 986.77 & 207 & & & & \\
\hline \multicolumn{6}{|c|}{ Комплексни елементи технике пењања } & \\
\hline Извор варијаиије & SS & $d f$ & MS & $F$ & Р-вредност & F критична \\
\hline Између група & 48.59 & 15 & 3.239 & 0.598 & 0.866 & 1.826 \\
\hline Унутар групе & 346.80 & 64 & 5.419 & & & \\
\hline Укупно & 395.39 & 79 & & & & \\
\hline
\end{tabular}

На основу резултата ANOVA може се констатовати да није утврђена статистички значајна разлика између посматраних парова варијабли анализираних група техничких елемената у функцији пола.
Структура такмичарске активности код пењача на леду, дисциплина тежинско пењање, конкуренција мушкарци и конкуренција жене, имала је следеће атрибуте и вредности (Табела 3). 
Табела 3. Структура такмичарске активности у обе конкуренције

\begin{tabular}{|c|c|c|}
\hline $\begin{array}{c}\text { Структура такмичарске } \\
\text { активности }\end{array}$ & Мушкарци & Жене \\
\hline Укупно време пењања & $224.52 \pm 98.81 \mathrm{~s}$ & $219.09 \pm 62.11 \mathrm{~s}$ \\
\hline Активно време пењања & $\begin{array}{c}103.88 \pm 48.97 \mathrm{~s} \\
(45.20 \pm 5.67 \% \text { у односу на укупно време пењања) }\end{array}$ & $\begin{array}{c}108.52 \pm 31.37 \mathrm{~s} ; \\
(50.34 \pm 8.99 \% \text { у односу на укупно време пењања) }\end{array}$ \\
\hline Паузе & $\begin{array}{c}119.66 \pm 50.40 \mathrm{~s} \\
(54.52 \pm 5.38 \% \text { у односу на укупно време пењања) }\end{array}$ & $\begin{array}{c}110.58 \pm 41.42 \mathrm{~s} ; \\
(49.66 \pm 8.99 \% \text { у односу на укупно време пењања) }\end{array}$ \\
\hline $\begin{array}{c}\text { Tрајање појединачног } \\
\text { активног покрета }\end{array}$ & $6.98 \pm 3.69 \mathrm{~s}$ & $6.77 \pm 2.10 \mathrm{~s}$ \\
\hline $\begin{array}{c}\text { Број активних покрета у току } \\
\text { једне такмичарске трке }\end{array}$ & $\begin{array}{c}14.38 \text { понављања } \\
\left(\begin{array}{c}54.96 \% \text { у односу на број укупно реализованих } \\
\text { покрета) }\end{array}\right. \\
\end{array}$ & $\begin{array}{c}16.75 \text { понављања } \\
(55.75 \% \text { у односу на број укупно реализованих } \\
\text { покрета) } \\
\end{array}$ \\
\hline Појединачна пауза & $10.16 \pm 5.68 \mathrm{~s}$ & $8.60 \pm 3.16 \mathrm{~s}$ \\
\hline $\begin{array}{c}\text { Број појединачних пауза у } \\
\text { току једне такмичарске трке }\end{array}$ & $\begin{array}{c}11.63 \text { понављања; } \\
\left(\begin{array}{c}45.04 \% \text { у односу на број укупно реализованих } \\
\text { покрета) }\end{array}\right. \\
\end{array}$ & $\begin{array}{c}13.5 \text { понављања } \\
(44.25 \% \text { у односу на број укупно реализованих } \\
\text { покрета) } \\
\end{array}$ \\
\hline $\begin{array}{c}\text { Најчешће реализована } \\
\text { техника }\end{array}$ & техника спајање руку 7.38 2.77 понављања & техника копчање са $4.63 \pm 2.45$ понављања \\
\hline
\end{tabular}

Анализом нотационог листа, утврђено је да мушкарци нису користили следеће технике пењања: опружање леве рука горе десно, и обрнуто, фигура 9, лева рука доле право и лева рука доле лево. У узорку жена није утврђено коришћење техника пењања лева рука горе десно и обрнуто, фигура 9, лева рука доле право, десна рука доле праве, десна рука доле десно.

\section{ДИСКУСИЈА}

Циљ ове анализе био је да се утврде квантитативне карактеристике дескриптивног профила основних параметара такмичарске активности код пењача на леду оба пола (мушкарци и жене), у дисциплини тежинско пењање. На основу резултата дескриптивних показатеља просечних временских параметара током једне такмичарске трке код мушкараца и жена (Табела 1), може се тврдити да вредност коефицијента варијације у укупном, активном и пасивном времену пењања-паузе код мушкараца прелази 30\%, код апсолутних показатеља, док код жена вредност укупног и активног времена пењања се креће испод $30 \%$, а пасивног времена пењања износи изнад $30 \%$.

Добијени резултати, код мушкараца, се могу тумачити као последица неуједначености трајања покрета - темпа пењања код свих такмичара. Претпоставља се да такмичари који су искуснији и успешнији једноставније и лакше елементе технике изводе брже како би сачували енергију за теже деонице. Насупрот томе, такмичари који су мање искусни бирају темпо пењања који је спорији, односно изводе дате елементе технике са мањим нивоом ефикасности, а вероватно и уз нижи ниво економичности.

Резултати указују на уједначеност трајања активних покрета, као и укупног времена пењања код жена. Могући узрок великих одступања од просечних резултата код пасивног времена пењања може бити резултат такмичарске припреме, али и такмичарског искуства, јер је пракса показала да лошије пласиране такмичарке проводе више времена у паузи, размишљајући који је њихов следећи потез, док успешније такмичарке то решавају са краћим или чак без непотребног задржавања.

На основу добијених резултата који су приказани у Табели 3 и која показује основне дескриптивне показатеље просечног трајања појединачних реализованих техника пењања (покрета-кретања) код мушкараца и жена током једне такмичарске трке, може се закључити да је код мушкараца укупан број активних покрета током једне трке износио 14.38 понављања (54.96\% у односу на укупно време трке), док паузе у просеку има 11.63 понављања (45.04\%) у односу на укупан $\delta р о ј$ покрета. Овакви резултати показују да активних покрета, бројчано, током једне такмичарске трке има више у односу на пасивне покрете. Жене, током једне трке просечно примењују 16.75 активних покрета (55.75\%), и паузе 13.5 пута (44.25\%). Жене, за разлику од мушкараца проводе више 
времена у активном извођењу покрета, а незнатно мање времена проводе у паузи (пасивни покрети).

Када се анализирају релативни показатељи добијених резултата, утврђено је да је активно време пењања код мушкараца износило 45.20\%, док је код жена износило $50.34 \%$ у односу на време трајања целе трке. Овакав резултат је део разлике у темпу који своје порекло има у поретку, ефикасности и економичности покрета и кретања, али је и вероватно последица пола, као и боље тренажне и такмичарске припреме, која је суштина сваке брзине кретања. Активно време пењања код жена је дуже, највероватније због већег броја покушаја постављања алатке, или забадања ногу у праву позицију. Уколико такмичар не успе из првог покушаја да пронађе најбољи ослонац за хват и упориште, онда он свој покрет може понављати без паузе до жељеног исхода. Будућа истраживања би требало да узму у обзир и врсту активног покрета, да ли је сврсисходан или не, односно да се реализовани елементи технике анализирају кроз аспект примењене тактике пењања. Поред тога, укупно трајање пењања се креће око 224 секунда, што имплицира и комплексна метаболичка дешавања до којих долази услед топографски целовитог ангажовања мишићног система ,као у ретко ком спорту. Не сме се занемарити константно деловање силе гравитације која од спортисте захтева додатно ангажовање у супротстављању њеном интензитету.

Када се анализира релативно трајање паузе уочава се да она током једне такмичарске трке код мушкараца има удео од 54.52\% у односу на укупно време пењања, док код жена пасивно време пењања има удео од 49.66\%. Порекло ове разлике у резултату може бити и то што је мушкарцима потребно дуже време одмора због веће мишићне масе које поседују у односу на жене. Такође, жене можда проводе мање времена одмарајући се због рационалности и предоминантности метаболизма протеина и масти у процесу добијања енергије у односу на мушкарце(метаболички критеријум) или се пењу без много непотребних задржавања (технички критеријум). Пауза на стени никако не представља потпун одмор, већ је иста период трајања замора, па чак и његове специфичне статичке компоненте. Замор у спорту је комплексне природе и још увек је недовољно изучен. У основи тог замора је привремено нарушена унутрашња равнотежа организма, нешто што се данас дефинише као алостаза - хомеостаза чија је основна последица смањена радна способност (Фратрић, 2015). Смањена такмичарска способност, уколико дуго траје може довести до потпуног губљења конкурентности и довести до краја наступа једног спортист. 3бог тога је неопходно да такмичари приликом свог наступа пажљиво планирају баланс између опоравка и замора. Смањење такмичарског потенцијала спортисте у кратком временском року је пре свега условљено метаболичким променама, као одговор организма на високо интензивне активности (Вељовић и сар., 2012.). Пут енергетског обезбеђења пењања је одређен такмичарским атрибутима у односу на пол. Оба пола до такмичарског резултата приоритетно долазе кроз технику. У другом и трећем кораку се разликују по томе што жене доминантно свој резултат граде на издржљивости, а потом на снази, док је снага код мушкараца на другом, а издржљивост на трећем месту.

Високо интензивне активности не узрокују само физички, већ и интелектуални, сензорни и емоционални замор. За анализу у односу на пол, била би интересантна и значајна анализа о неуроендокрином пореклу замора, конкретно о учешћу анаболичких хормона - симпатичког порекла у односу на катаболичке хормоне (парасимпатичког порекла). Заједничко за све наведене типова замора је утицај на способност одлучивања, бирање најбољег смера кретања и примењивање најадекватније технике... Свакако да је и осећај темпа под високим степеном замора „угрожена“ категорија.

У Табели 3 приказани су основни дескриптивни показатељи учесталости реализације елемената технике пењања код мушкараца и жена током анализиране такмичарско-пењачке трке. Нотационом анализом такмичарске активности утврђено је да на такмичењу у Пекингу нису биле примењиване одређене технике пењања (десна рука горе лево, лева рука горе десно, лева рука доле право, десна рука доле право, лева рука доле лево, фигура 9). Претпоставка је да се покрети укрштања (десна рука горе лево, лева рука горе десно) не појављују на такмичењима пењања на леду због техничке комплексности извођења и физичке захтевности, односно да конфигурација стене и постављен такмичарски смер нису захтевали употребу осталих техника. Даљим истраживањима 
ове спортске дисциплине која би била проширена на остала такмичења UIAA у пењању на леду могла би верификовати ову претпоставку.

На основу резултата коефицијента варијације за све елементе технике од преко 30\% код мушкараца имплицира на вишестрани начин решавања проблема пењања сваког такмичара (индивидуални приступ изградњи такмичарског резултата). Такмичари су користили различите технике за прелазак истих препрека на такмичарској стази. Код жена, вредност коефицијента варијације је мањи од 30\%, само код технике опружања десне руке горе право и износи $14.24 \%$. Овакав резултат може значити да је већина такмичарки на исти начин решавала проблем или да је смер био постављен тако да га је датом техником било најлакше и најефикасније савладати. На основу резултата Студентовог t-теста разлика временских показатеља трке између мушкараца и жена, утврђено је да нема статистички значајних разлика ни у једној од анализираних варијабли. На основу добијених резултата закључено је да је укупно време пењања, просечно код мушкараца износило 224.52 секунде, док је код жена износило 219.09. Овакви резултати говоре о сличној структури временских параметара такмичарске активности код мушкараца и жена, иако се они такмиче на различитим такмичарским стазама (смеровима), на стени исте конфигурације. На основу резултата анализе варијансе - ANOVA посматраних парова варијабли анализираних група техничких елемената у функцији пола није утврђена статистички значајна разлика ни код једне анализиране варијабле (Табела 2). Овакав резултат говори да се структура техника које примењују мушкарци и жене на такмичењу не разликује, иако се они пењу различитим смером, на истој конструкцији, тј. стени. Дакле, цео проблем се враћа на временске параметре, тачније темпо кретања који, како резултати показују значајно утиче на поредак такмичара. Одабир одговарајућег и најефикаснијег темпа кретања зависи од ритма, когнитивне стране такмичара, али и карактеристика опште и специфичне тренажно-такмичарске припреме која претходи такмичењу. Оно што је важно истаћи, гледајући са теоријске стране која може бити од користи у примени у овом младом спорту, а то је и чињеница да темпо припада временским параметрима кретања, те да они своје порекло воде из делова моторне коре у којима се не налазе параметри за просторну страну кретања. Другим речима, просторни и временски параметри кретања се памте у различитим деловима моторне коре, односно, учење и усвајање истих је узрасно детерминисано. Временски координациони параметри су условљени раним учењем и специјализацијом, док су просторни одређени параметрима мишићне силе, али и морфолошким карактеристикама спортиста (Јевтић, 2011). Стога, за развој пењања на леду, један од првих задатака је поставка квалитетне теорије, методике и технологије тренинга. На том путу важно би било и сачињавање програма вишегодишњег плана и програма развоја спортисте, све у функцији специјализације за изазове ове екстремне спортске дисциплине.

\section{ЗАКЉУЧАК}

Предмет ове анализе је био утврђивање структуре такмичарске активности у дисциплини тежинско пењање пењача на леду у функцији пола и темпа.

Структура анализиране такмичарске активности код пењача на леду има прихватљиве и поуздане карактеристике централних и дисперзивних статистичких параметара. Иако се мушкарци и жене на такмичењу пењу различитим смером и за то имају различито, унапред одређено време, није утврђена разлика између профила такмичарске активности код пењача на леду у функцији пола, ни у погледу временских параметара (темпа), ни у погледу врсте примењиване технике.

Даља истраживања би требало да имају циљ, да на основу разматрања специфичних карактеристика спортиста дођу до кnow-how знања и-или техничке вештине које се односе на процедуре, процесе, програме, стандарде... како у контексту специјализације, тако и у простору сазнања феномена и филозофије самог пењања на леду.

Резултати добијени овим истраживањем могу да послуже за моделирање тренинга такмичара који ће учествовати на UIAA светским куповима у пењању на леду са крајњим циљем побољшања ефикасности и постизања успеха на такмичењу.

Знања и информације о просечном трајању такмичарске трке, темпа кретања, трајању одмора и напора, врсти и учесталости примењиваних техника омогућиће тренерима и спортистима да лакше разумеју ову релативно нову такмичарску дисциплину. 
Резултати ове студије могу да послужи за даље унапређење такмичарске активности код дисциплине пењање на леду. Будућа истраживања би ради добијања комплетније слике о структури такмичарске активности врхунских пењача на

\section{ЛИТЕРАТУРА}

1. Боженко, А. (1997). Основе йеорије и мейоgике іиренині̄a фуggбалера. Београд. Самостално издање аутора.

2. Фратрић, Ф. (2015). Теорија и метиоgика

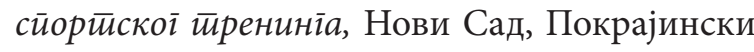
завод за спорт

3. Jevtić, B. (2011). Dečiji uzrast i razvoj koordinacionih sposobnosti: primer iz sportskog plivanja. U B. Jevtic, J. Radojević. I. Juhas \& R. Ropret (Ed). Dečiji sport od prakse do akademske oblasti (pp. 187-197). Beograd. Fakultet sporta i fizičkog vaspitanja.

4. Lead Finals Ice Climbing World cup 2017 Beijing. https://www.youtube.com/ watch? $\mathrm{v}=4 \mathrm{vB}$ $\mathrm{w} 8 \mathrm{NTuD} 5 \mathrm{c} \& \mathrm{t}=6224 \mathrm{~s}$ (dostupno 14.07.2017.)

5. Majstorović N., Sikimić M., Osmankač N., Grbić V. (2015). Analiza takmičarske aktivnosti u završnici „WIENER STADTISCHE” lige Srbije za odbojkaše u sezoni 2012/2103. Fizička kultura, 69 (1), 51-58.

6. Mashkovskiy E., Beverly J.M., Stöcker U., Bychkovskiy S. (2009). Ice Climbing Festival in Sochi 2014 Winter Olympics: Medical Management and Injury Analysis. Wilderness \& Environmental Medicine, 27, 117-124 леду и ради потврђивања или оповргавања претпоставки овог рада, требало да укључе сва такмичења која се одржавају у оквиру UIAA светског купа у пењању на леду.

7. Нешић, Г. (2002). Основи анирройомойорике. Београд: Спортска академија.

8. Нешић Г. (2006). Сӣрукииура тиакмичарске

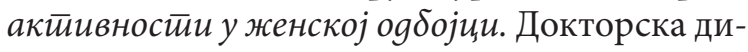
сертација. Београд. Факултет спорта и физичког васпитања.

9. PractICE Climbing in Competition, Athletes Manual, UIAA Bern.

10. Seifert L., Wattebled L., Herault R., Poizat G., Ade' D., et al. (2014). Neurobiological Degeneracy and Affordance Perception Support Functional Intra-Individual Variability of Inter-Limb Coordination during Ice Climbing. PLoS ONE 9(2): e89865.hidoi:10.1371/journal.pone.0089865

11. Важни, 3. (1978). Систем спортског тренинга. Београд: Новинско издавачко предузеће Партизан.

12. Viner I.A., Terekhina R.N., Pirozhkova E.A. (2012). Analysis of competitive activity of gymnasts in group exercices on the eve of the XXX Olympic games. Uchenyezapiskiuniversitetaimeni P.F. Lesgafta, 76(4), 26-31.

13. Вељовић Д., Међедовић Б., Остојић СМ. (2012). Опоравак врхунских спортиста: преглед савремених метода, ТИМС, Acta 6(1), $10-18$. 


\title{
ANÁLISIS DE LAS ACTIVIDADES COMPETITIVAS DE LOS ESCALADORES EN HIELO
}

\begin{abstract}
Resumen
La disciplina competitiva de escalada en hielo, surgió respondiendo a la escalada en cataratas congeladas y se puede definir como una disciplina deportiva particular que se desarrolla bajo el auspicio y proposiciones de la Federación Internacional de Asociaciones de Alpinismo (UIAA). Se desarrolla en las condiciones artificiales prescritas y bajo determinadas reglas. Por falta de trabajos sobre la actividad motriz de escaladores en hielo de alto rendimiento, el objetivo del presente trabajo es establecer la estructura de la actividad competitiva de los escaladores en hielo en las dos competencias (hombres y mujeres), en la disciplina escalada de plomo. Se analizan las dos competencias porque en esta disciplina deportiva por la discriminación positiva y por los atributos más débiles del organismo femenino para la escalada, las proposiciones prescriben que mujeres y hombres tienen distintas direcciones de escalada. Por esto, la muestra de los examinados se hizo de los finalistas de la copa mundial de UIAA en Pekín (2017) en la disciplina escalada de plomo y fueron 8 hombres y 8 mujeres. El método de trabajo es análisis de la actividad competitiva aplicando la técnica de análisis de notación. Se estableció que el tiempo promedio de duración de la carrera competitiva en los hombres ascendió a 224,52 $\pm 98,81$ segundos, de lo que el tiempo activo de escalada ascendía a $103.88 \pm 48.9$ segundos y el tiempo pasivo de escalada - pausa ascendió a $110.58 \pm 41.42$ segundos. Aunque los hombres y mujeres en la competencia escalan por distintas direcciones, este análisis no estableció la diferencia entre la estructura de la actividad competitiva en función del sexo, como tampoco en cuanto al ritmo de escalada y tipo de técnica aplicada. Los resultados de este análisis pueden tener importancia excepcional para los entrenadores en su trabajo práctico para la preparación directa de los competidores para la participación en las competencias de UIAA.
\end{abstract}

Palabras claves; ESCALADA EN HIELO / ANÁLISIS DE ACTIVIDAD COMPETITIVA / RITMO / UIAA

Примљен: 03.05. 2018

Прихваћен: 05. 06. 2018 